\title{
India's Tryst with the Asian Century
}

\begin{abstract}
As the Asian Century draws near, India faces three choices for how it can navigate geopolitically turbulent times. It can align closely with the US and the Quad, integrate itself into an Asian ecosystem of trade and peace, or become an independent pole in new multilateral world order.
\end{abstract}

Geopolitics is a cruel game. It rewards cunning and calculating moves and punishes emotional responses. In the twenty-first century, as we move into an era of massive power shifts, geopolitical nimbleness will become even more critical for all countries. In this regard, India is one of the most fortunate countries. Given its size and political heft, it has more choices than most. Yet, it too has to choose wisely. Each choice has benefits but also costs.

The first choice is obvious. To balance China's growing weight and influence, especially after the tragic clash at the Sino-Indian border in June, India could drift toward becoming an ally of the US. Many influential voices are advocating this option, which has many merits. Despite its problems, the US remains the world's number one economic and military power. By joining the Quadrilateral Security Dialogue, or the Quad, together with Australia and Japan, India is sending a strong signal that it is moving in that direction. Undoubtedly, the US has been generous to India, especially under former president George W. Bush, under whose leadership the US signed the civil nuclear agreement with India, thereby paving the way for global recognition of India as a nuclear power.

By aligning itself with the US, India would be making a choice similar to one made by China, which aligned itself with the US and Pakistan against the Soviet Union and India in the Cold War. It was truly cunning of China to forget its differences with the US when Henry Kissinger visited them in 1971. China simply ignored the fact that the US still recognized Taiwan as the official government of China. In return, China got many benefits. The CIA stations in Xinjiang provided some protection from the Soviet threat. Equally crucial, the US generously opened up its market and integrated China into the liberal rules-based order. As a result, China's gross national product,

Originally published in India Today, Jul 18, 2020 
one-tenth the size of the US in purchasing power parity terms in 1980, became bigger than the US in 2014. China should thank the US for its exceptional economic success.

Sadly, in 2020, the US can no longer be as generous. It is the only major developed society where the average income of the bottom $50 \%$ has gone down over a 30 -year period, creating, as two Princeton University economists have documented, a "sea of despair" among the white working classes. Local jobs are protected. Hence, in mid2020, the Trump administration canceled H1B visas and visas for overseas students, hurting many Indians. Equally importantly, Adam Garfinkle, the long-time editor of The American Interest, has wisely warned many Asian countries to not expect the US to continue playing a major role in Asia. He says, "It's too bad that it's all over now. Yes, it's gone, not coming back." He is right. History teaches us that great powers recede when their domestic problems take priority, just as the British retreated from East of Suez. So, even though Japan and Australia remain staunch allies of the US today, they might be secretly planning for alternative scenarios.

The second choice for India is to join a new silent ecosystem of peace and prosperity evolving in East Asia. With the US retreating from FTAs (free trade agreements), East Asia is persisting with them, keeping alive even the Trans-Pacific Partnership (TPP) that the US walked away from. This system is ASEAN-centered. The paradox here is that since ASEAN is weak and nonthreatening, everyone trusts it. Hence, ASEAN has signed FTAs with all of its East Asian partners, including India. These FTAs were further consolidated into the Regional Comprehensive Economic Partnership (RCEP), which all partners of ASEAN, except India, have joined. India's concerns over another surge of imports from China after joining RCEP are valid. Yet, a bilateral safeguards agreement can take care of it.

The East Asian ecosystem has delivered prosperity and rests on a culture of peace, pragmatism and competence. Covid has proven how competent East Asian societies have become. As of May 25, 2021, the number of Covid deaths per million is much lower in East Asia (South Korea, 37.34 Japan, 96.9; China, 3.5; Singapore, 5.6; and Vietnam, 0.4 compared to the West (Spain, 1695.8; Italy, 2037.4; Belgium, 2167.6; UK, 1916.2; and US, 1778.5). ${ }^{1}$ This confirms that the shift of competence from the West to East Asia is gaining momentum.

Managing the rise of China is the biggest challenge for the East Asian ecosystem. Differences persist over the South China Sea, the Diaoyutai/Senkaku Islands. Wars could break out. Yet, amazingly, the guns have been silent for over three decades. A quiet culture of pragmatism has become the norm. There is one clear point of agreement among the East Asian states: now is the time to focus on economic growth and development and the eradication of poverty. This explains why the ASEAN region, once one of the world's poorest, will become the fourth largest economy of the world by 2030. Pragmatism pays.

The third choice for India is to emerge as an independent pole in new multipolar world order. Clearly, as I document in Has China Won?, the world will be rocked by a major geopolitical contest between the US and China in the coming decades.

\footnotetext{
${ }^{1}$ Data updated, https://www.who.int/publications/m/item/weekly-epidemiological-update-oncovid-19---25-may-2021.
} 
This contest could not come at a worse time. Our imperiled planet faces many challenges, global warming, and a global recession caused by Covid. If the two countries continue with their struggle, future historians may well see them as two tribes of apes fighting each other while the forests around them burn. Common sense would dictate otherwise.

This may also explain why few countries are rushing to take sides. Many traditional Asian allies of the US, including the Philippines and Thailand, Japan and South Korea, do more trade with China than with the US. South Korea and Japan are also alarmed that the economic bill for the US soldiers stationed on their soil has skyrocketed, leading them to ask if they are allied soldiers or mercenaries. Yet, as Garfinkle has pointed out, the US has to take care of its own interests first.

The one country big enough to emerge as an independent pole and provide common sense and calm leadership in a geopolitically turbulent world is India.

India has also been a champion of multilateralism. Working with the European Union, India could provide global leadership by speaking truth to power. The world is yearning for such an independent leader. One story tells it all. In the mid-1990s, Japan ran against Bangladesh for a seat on the UN Security Council and lost. While I was serving as the Singapore ambassador to the UN, I asked the African states why they didn't vote for Japan. They said, "Why give two votes to the US in the UNSC?".

None of these three choices will be easy options for India. Each will have its share of benefits and costs. Hence, it would be wise for India to explore carefully all its options before making its final choice. One advantage India has is that it has a strong leader. Its biggest strength is that it has more choices than virtually any other nation today.

\footnotetext{
Open Access This chapter is licensed under the terms of the Creative Commons AttributionNonCommercial-NoDerivatives 4.0 International License (http://creativecommons.org/licenses/bync-nd/4.0/), which permits any noncommercial use, sharing, distribution and reproduction in any medium or format, as long as you give appropriate credit to the original author(s) and the source, provide a link to the Creative Commons license and indicate if you modified the licensed material. You do not have permission under this license to share adapted material derived from this chapter or parts of it.

The images or other third party material in this chapter are included in the chapter's Creative Commons license, unless indicated otherwise in a credit line to the material. If material is not included in the chapter's Creative Commons license and your intended use is not permitted by statutory regulation or exceeds the permitted use, you will need to obtain permission directly from the copyright holder.
}

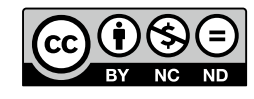

